\title{
TIME-SERIES ANALYSIS OF COASTAL EROSION IN THE SUNDARBANS MANGROVE
}

\author{
M. Mahmudur Rahman \\ Bangladesh Space Research \& Remote Sensing Organization (SPARRSO), Agargaon, Sher-E-Bangla Nagar, Dhaka- \\ 1207, Bangladesh - Mahmud_Rahman_2861@yahoo.com,mahmud@sparrso.gov.bd
}

Commission VIII, WG VIII/7

KEY WORDS: Mangroves, Sundarbans, Erosion, Climate Change

\begin{abstract}
:
Mangrove forests are fragile coastal ecosystems and could be one of the most vulnerable ecosystems to global climate change and sea-level rise. These forests are formed in the fringe of land and ocean and characterized by the regular inundation of tidal water. Because of the changes in sea-level and dynamic energy system in the transition zone between land and sea due to climate change, erosion in different coastal zones of the world could be accelerated. The objective of this study is to find out the nature and pattern of erosion that can threaten mangrove forest ecosystems. The study area is located in Sundarbans mangrove, the largest continuous mangrove forest in the world. The study utilized time-series data of Landsat Multi-spectral Scanner (MSS), Thematic Mapper (TM) and Enhanced Thematic Mapper Plus (ETM+) during 1970s to 2010s. Time-series change analysis was done along the selected transect lines. The erosion rates in the Sundarbans Mangrove are variable and it is very difficult to get a conclusive result from the analysis of those points whether the erosion rate has been accelerated in the recent past. The average rates of erosion for the eastern and western parts are $14 \mathrm{~m} /$ year and $15 \mathrm{~m} /$ year respectively obtained form the ten selected transect lines. It is unclear that how much coastal erosion is linked to the global warming and sea-level rise or whether any other associated factors such as geological and anthropogenic induced land subsidence, changes in sediment supply or other local factors are driving these changes. Further studies should be conducted in different mangrove ecosystems of the world to explore whether similar patterns of coastal erosion are visible there.
\end{abstract}

\section{BACKGROUND}

The threat of global climate change is the consequence of industrial activities that includes accelerating rate of $\mathrm{CO}_{2}$ emission. The experimental results of Manua Loa has reported a rapid increase in the mixing ratio of $\mathrm{CO}_{2}$ concentration in the atmosphere rising from $315 \mathrm{ppm}$ in 1960 to around $390 \mathrm{ppm}$ in 2010 (Tans 2010). Since the industrial revolutions, $\mathrm{CO}_{2}$ concentrations in our atmosphere increased in faster rate, and are now 30\% greater than pre-industrial time (Reay and Grace 2007). The rapid increase in $\mathrm{CO}_{2}$ emissions observed during the last 250 years is assumed to continue for several forthcoming decades and likely to create many adverse impacts in our living system.

The consequences of climate change are in various dimensions like changes in arctic temperatures and ice, widespread changes in precipitation amounts, ocean salinity, wind patterns and aspects of extreme weather including droughts, heavy precipitation, heat waves and the intensity of tropical cyclones, shoreline changes and inundation of low-lying areas (Adapted from IPCC 2007). Sea-level has been rising 1.7-1.8 $\mathrm{mm} /$ year over the last century and the rate has increased to $3 \mathrm{~mm} /$ year in the last decade (Church et al. 2004, Holgate and Woodworth 2004, Church and White 2006, Bindoff et al. 2007) though there is an absence of more accurate regional scenarios (i.e. for Bay of Bengal). Sea level rise over the last $100-150$ years is probably contributing to coastal erosion in many places of the world (Rosenzweig et al. 2007).

Mangrove vegetation is threatened due to coastal erosion, declined freshwater flow from the hinterland and the increased level of salinity in many deltas. Mangrove ecosystem is characterized by the regular inundation of tidal water. The fresh-water flow from the inland and the tidal waves from the sea play a crucial role in the formation and the dynamics of this fragile ecosystem. This forest is the most vulnerable to global climate change and sea-level rise in addition to other anthropogenic and natural causes.

Sea-level rise is currently measured at $3.24 \mathrm{~mm}$ per year (UNEP 2004) that can threaten to unbalance the Sundarbans mangrove forest water forces. Although the change in waterline is very small, but changes in a dynamic energy system can be a severe threat, which already bring periodic catastrophes in the region. Various studies have already found that Sundarbans forest has been lost $85 \mathrm{~km}^{2}$ over 20 years and $200 \mathrm{~km}^{2}$ of land over 70 years (UNEP 2004). The objective of this study is to quantify the nature and pattern of coastal erosion in the Sundarbans mangrove, the largest continuous mangrove forest in the world.

\section{MATERIALS AND METHODS}

\subsection{Study Area and Data-sets}

Sundarbans forest is located in the southern extremity of the Ganges River Delta, extended about $80 \mathrm{~km}$ north of the Bay of Bengal and bounded by the Baleshar River on the east and by the Hoogly River on the west. Approximately two-thirds of the forests lie in Bangladesh, the remaining one-third in India.

The ground within the forest is extremely flat, and elevation more than $1.5 \mathrm{~m}$ above mean high tide level is seldom noticed. The predominant tree species in the forest are Sundri (Heritiera fomes) and Gewa (Excoecaria agallocha). Other species include Passur (Xylocarpus moluccensis), Kankra (Bruguiera 
cylindrica), Keora (Sonneratia apetala), Baen (Avicennia officinalis), Dhundal (Xylocarpus granatum), Goran (Ceriops decandra) and Golpata (Nypa fruticans).

Time-series Landsat data from 1972-2010 were used in this study. The list of data-sets is enumerated in Table 1 .

Table 1. Landsat scenes used in the study

\begin{tabular}{|c|c|c|c|c|}
\hline $\begin{array}{l}\text { Time- } \\
\text { frame }\end{array}$ & Data-sets & $\begin{array}{l}\text { Path- } \\
\text { row }\end{array}$ & Date & Use \\
\hline \multirow[t]{3}{*}{$\begin{array}{l}1972- \\
73\end{array}$} & \multirow{3}{*}{$\begin{array}{l}\text { Landsat } \\
\text { Multispectral } \\
\text { Scanner } \\
\text { (MSS) }\end{array}$} & 148044 & 19.12 .1972 & \multirow{3}{*}{$\begin{array}{l}\text { Image } \\
\text { classification } \\
\text { and change } \\
\text { analysis } \\
\text { Time-series } \\
\text { change } \\
\text { analysis } \\
\text { along the } \\
\text { lines }\end{array}$} \\
\hline & & 147045 & 20.02 .1973 & \\
\hline & & 148045 & 21.02 .1973 & \\
\hline \multirow[t]{2}{*}{1980} & \multirow[t]{2}{*}{$\begin{array}{l}\text { Landsat } \\
\text { MSS }\end{array}$} & 147045 & 15.01 .1980 & \multirow{4}{*}{$\begin{array}{l}\text { Time-series } \\
\text { change } \\
\text { analysis } \\
\text { along the } \\
\text { lines }\end{array}$} \\
\hline & & 148045 & 21.02 .1980 & \\
\hline 1989 & $\begin{array}{l}\text { Landsat } \\
\text { Thematic } \\
\text { Mapper } \\
\text { (TM) }\end{array}$ & 137045 & 12.01 .1989 & \\
\hline 2000 & $\begin{array}{l}\text { Landsat } \\
\text { Enhanced } \\
\text { Thematic } \\
\text { Mapper Plus } \\
(\text { ETM+) }\end{array}$ & 137045 & 28.02 .2000 & \\
\hline \multirow[t]{2}{*}{2010} & \multirow[t]{2}{*}{ Landsat TM } & 137045 & 30.01 .2010 & \multirow[b]{2}{*}{$\begin{array}{l}\text { Image } \\
\text { classification } \\
\text { and change } \\
\text { analysis } \\
\text { Time-series } \\
\text { change } \\
\text { analysis } \\
\text { along the } \\
\text { lines }\end{array}$} \\
\hline & & 138045 & 06.02 .2010 & \\
\hline
\end{tabular}

\subsection{Methodology}

Orthorectified Landsat images were downloaded from United States Geological Survey (USGS). Landsat images of 1972-73 and 2010 were classified based on the spectral subclasses identified on the digital images. Those classes were later merged to form desired land cover categories (Table 2). Maximum likelihood or minimum distance algorithm was applied in the classification procedure. Mangrove forest change map was prepared by overlaying classified images of 1970 s and 2010. The change map is the basis for computation of change statistics and generation of change matrix.

Time-series change analysis was done along the selected transect lines. Five transect lines were selected each for the eastern and western parts of Sundarbans located in Bangladesh. Eastern part is located at the east of Kunga River and western part is located at the west of the river. The lines were selected randomly from the eroded places noticed on 1973-2010 change image. The analysis was done in a decadal time-scale. The trends of erosion are investigated by digitizing on-screen the visible forest boundary on the digital Landsat scenes.

Table 2. Land cover definitions used in image classification

\begin{tabular}{|l|l|}
\hline $\begin{array}{c}\text { Land cover } \\
\text { categories }\end{array}$ & \multicolumn{1}{|c|}{ Definition } \\
\hline Mangrove & $\begin{array}{l}\text { The class represents natural mangrove } \\
\text { forest that excludes coastal plantation. }\end{array}$ \\
\hline $\begin{array}{l}\text { Other } \\
\text { vegetation }\end{array}$ & $\begin{array}{l}\text { The class consists of other vegetation } \\
\text { and includes homestead forest } \\
\text { vegetation, crops, coastal mangrove } \\
\text { plantation. }\end{array}$ \\
\hline Bare land & $\begin{array}{l}\text { This is a contemporary class. Most of } \\
\text { these areas belong to seasonal cropland. } \\
\text { The class includes sandy soil in the } \\
\text { offshore islands. }\end{array}$ \\
\hline Water & $\begin{array}{l}\text { The class represents all type of water- } \\
\text { bodies including sea, river, shrimp } \\
\text { farms, inland water bodies, agricultural } \\
\text { land flooded with water. }\end{array}$ \\
\hline
\end{tabular}

\section{RESULTS AND DISCUSSION}

\subsection{Changes in 1973-2010}

The overall changes in the Bangladesh part of Sundarbans are presented in Figure 1. Red color shows mangrove forest loss due to coastal erosion during the last four decades (1973-2010). Erosion is vivid in most of the peripheral zone of mangrove forest.

The change statistics reveals (Table 3) that the mangrove forests have been lost about $144 \mathrm{sq}$. $\mathrm{km}$ during the period of investigation. The loss of mangrove because of erosion was 233 sq. km, while conversion of sea-water to mangrove forest was $104 \mathrm{sq} . \mathrm{km}$. This is alarming since the loss of forest due to land erosion is higher than the forest aggradations. Land accretion and forest succession are also noticed in some places. But this phenomenon is usually concentrated only in some spots, not widely spread as coastal erosion

\subsection{Time-Series Change Analysis}

Time-series changes for the selected transect lines of Sundarbans forest have been analyzed (Figure 2 and 3 ) for eastern and western part of Bangladesh Sundarbans. Photographs of the eroded places obtained during the fieldmission of January 2012 are presented in Figure 4. The nature and patterns of coastal erosion responsible for forest loss are vivid in the pictures.

The rate $(\mathrm{m} /$ year) of erosion at the different points of the selected transect lines is presented in Table 4 . The erosion rates are variable and it is very difficult to get a conclusive result from the analysis of those points whether the erosion has been accelerated in the recent past due to man-made or climate induced factors. The average rates of erosion for the eastern and western parts are $14 \mathrm{~m} /$ year and $15 \mathrm{~m} /$ year respectively obtained form the ten selected transect lines. Further studies should examine it using different methods. 
International Archives of the Photogrammetry, Remote Sensing and Spatial Information Sciences, Volume XXXIX-B8, 2012 XXII ISPRS Congress, 25 August - 01 September 2012, Melbourne, Australia

Table 3. Land cover change matrix in Sundarbans forest regions (1973-2010, Bangladesh part), area in sq. km

\begin{tabular}{|c|c|c|c|c|c|c|}
\hline & \multicolumn{4}{|c|}{2010} & \multirow{2}{*}{$\begin{array}{l}\text { Total } \\
1973\end{array}$} \\
\hline & & Mangrove & $\begin{array}{l}\text { Other } \\
\text { vegetation }\end{array}$ & $\begin{array}{l}\text { Bare } \\
\text { land }\end{array}$ & Water & \\
\hline \multirow[t]{4}{*}{1973} & Mangrove & 3920 & 1 & 24 & 233 & 4178 \\
\hline & $\begin{array}{l}\text { Other } \\
\text { vegetation }\end{array}$ & - & 242 & 385 & 278 & 905 \\
\hline & Bare land & 10 & 79 & 597 & 307 & 993 \\
\hline & Water & 104 & 14 & 54 & 4538 & 4710 \\
\hline \multicolumn{2}{|c|}{ Total 2010} & 4034 & 336 & 1060 & 5356 & 10786 \\
\hline
\end{tabular}

Table 4. Time-series analysis of mean erosion rate (m/year) at different point

\begin{tabular}{|c|c|c|c|c|c|c|}
\hline Position & $\begin{array}{c}\text { Point } \\
\text { number }\end{array}$ & $\begin{array}{c}1972- \\
1980\end{array}$ & $\begin{array}{c}1980- \\
1989\end{array}$ & $\begin{array}{c}1989- \\
2000\end{array}$ & $\begin{array}{c}2000- \\
2010\end{array}$ & Direction \\
\hline \multirow{3}{*}{ East } & $\mathrm{A}$ & 20 & 9 & 17 & 20 & West \\
\cline { 2 - 7 } & $\mathrm{B}$ & 27 & -3 & 11 & 12 & West \\
\cline { 2 - 7 } & $\mathrm{C}$ & 37 & 6 & 12 & 14 & East \\
\cline { 2 - 7 } & $\mathrm{D}$ & 24 & 11 & 9 & 19 & North-west \\
\cline { 2 - 7 } & $\mathrm{E}$ & 2 & 18 & 11 & 12 & $\begin{array}{c}\text { East, } \\
\text { South-east }\end{array}$ \\
\cline { 2 - 7 } & Mean & 22 & 8 & 12 & 15 & \\
\hline \multirow{4}{*}{ West } & $\mathrm{A}$ & -5 & 24 & 22 & 23 & South-west \\
\cline { 2 - 7 } & $\mathrm{B}$ & -1 & 17 & 17 & 15 & North-west \\
\cline { 2 - 7 } & $\mathrm{C}$ & -6 & 16 & 11 & 23 & South-west \\
\cline { 2 - 7 } & $\mathrm{D}$ & -20 & 11 & 53 & 2.7 & North-west \\
\cline { 2 - 7 } & $\mathrm{E}$ & 23 & 27 & 28 & 26 & East \\
\cline { 2 - 7 } & Mean & -2 & 19 & 26 & 18 & \\
\hline
\end{tabular}

Minus sign represents accretion

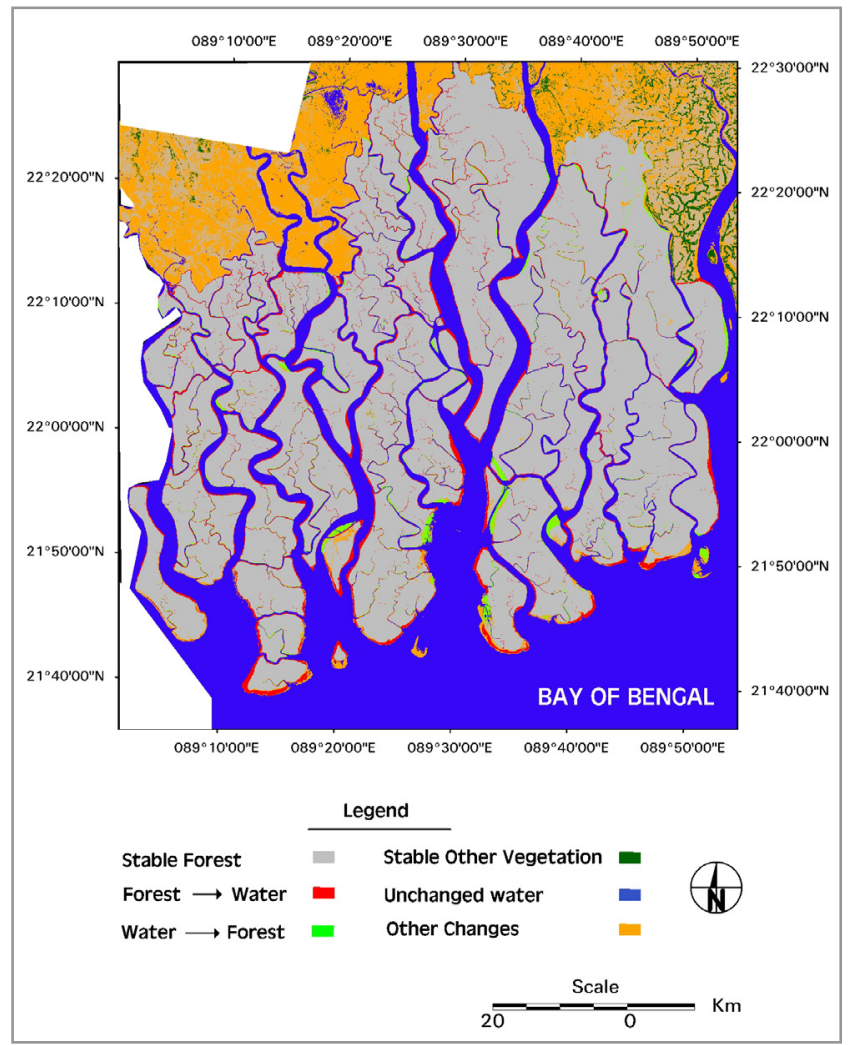

Figure 1. Shoreline changes in the Sundarbans mangrove forest (Bangladesh part, 1973-2010) 


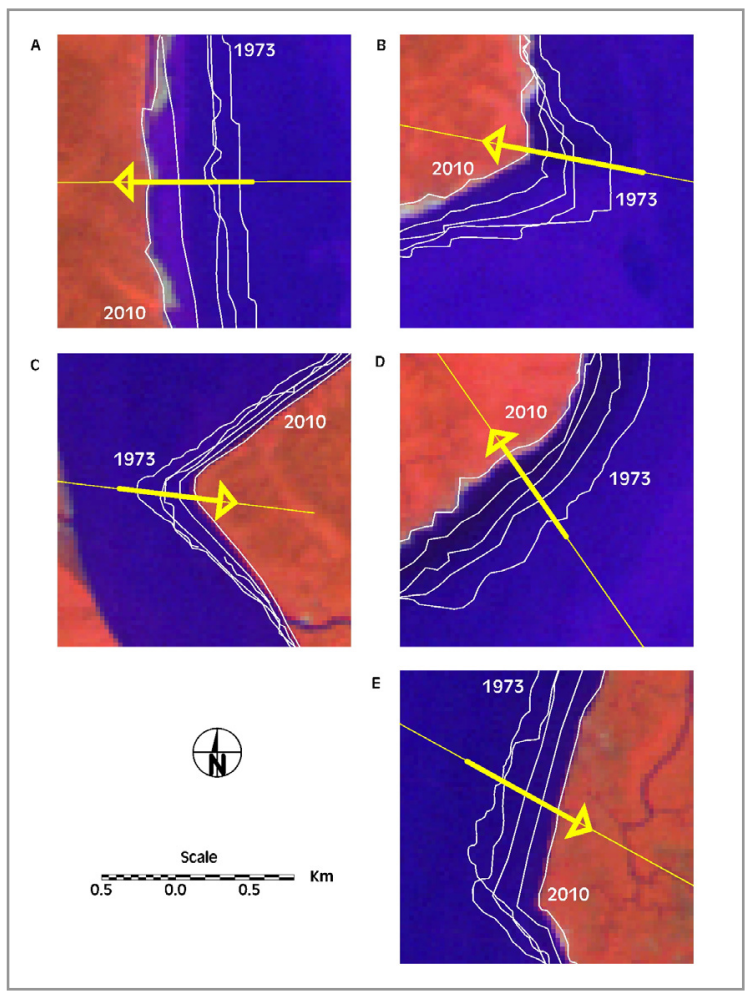

Figure 2. Demonstration of time series coastal erosion (1973-2010) in the eastern part of Sundarbans (Bangladesh part)

Coastal erosion in the Sundarbans is also reported in Giri et al. (2007) for 1973-2000. According to that investigation covering the whole of Sundarbans (both in India and Bangladesh), between 1970s and 1990s, mangrove forest expanded from land accretion (29 sq.km) nearly equals to the loss of mangrove forest by erosion (32 sq.km). However, from 1990s to 2000s, erosion (42 sq. $\mathrm{km})$ was seven times greater than accretion $(6$ sq. km).

\section{CONCLUSION}

It is concluded in the study that (1) Sundarbans forest is experiencing coastal erosion, which is widespread in many parts of the peripheral zone and (2) the total forest loss due to coastal erosion is $233 \mathrm{~km}^{2}$ that is higher than the total aggradations of forest from sea, which is $104 \mathrm{~km}^{2}$ in the Bangladesh part during the period of investigation (1973-2010) and (3) the rate of coastal is erosion is variable in different parts of Sundarbans.

Sundarbans forest is shrinking due to the coastal erosion though it is not clear yet how much coastal erosion is linked to the global warming and sea-level rise. Further studies should explore how much coastal erosion is linked to the global warming or the result of geological or anthropogenic induced land subsidence, changes in the sediment supply from the eastern Himalayan catchments or because of any other local factors.

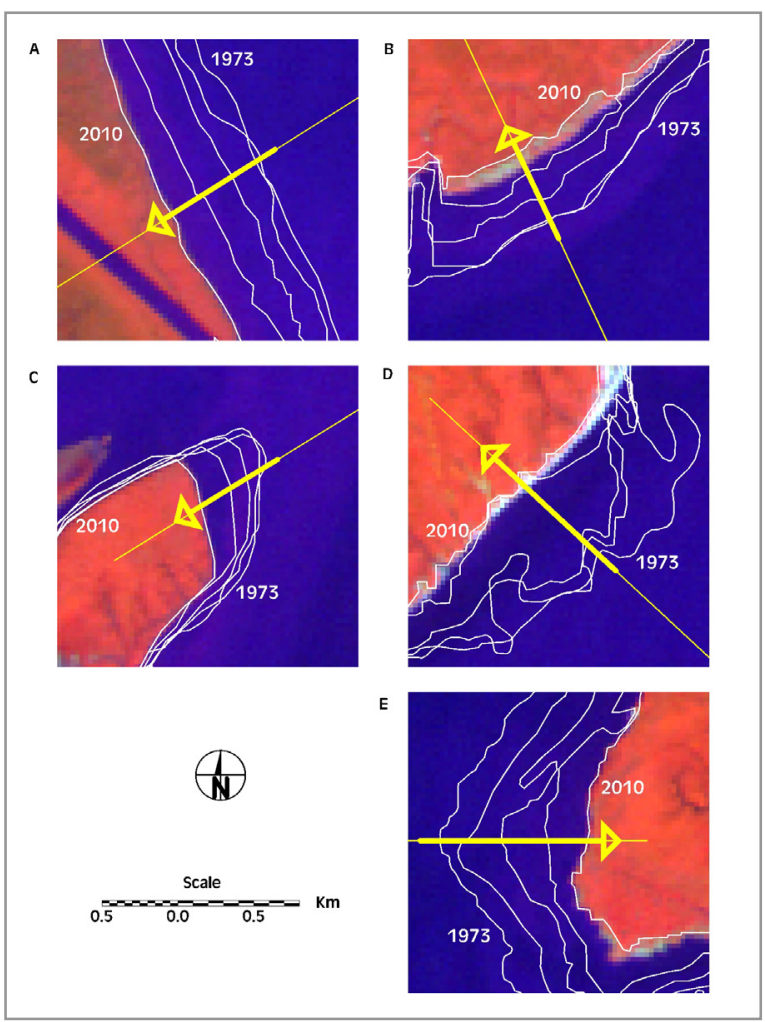

Figure 3. Demonstration of time series coastal erosion (1973-2010) in the western part of Sundarbans (Bangladesh part)

\section{ACKNOWLEDGEMENTS}

The author would like to thank Shaheen Khan, Chairman of SPARRSO to grant permission to publish the work. Landsat images were downloaded from United States Geological Survey (USGS). Bangladesh Forest Department is acknowledged for their assistance during field visits. Sultana Razia of SPARRSO helped to digitize some parts of the work.

\section{REFERENCES}

Bindoff, N., Willebrand, J., Artale, V., Cazenave, A., Gregory, J, Gulev, S. et al. 2007. Observations: Oceanic climate change and sea level. In: Solomon, S. et al. (eds.), Climate Change 2007: The Physical Science Basis. Fourth Assessment Report of IPCC, pp. 387-432.

Church, J. A. and White, N. J., 2006. A $20^{\text {th }}$ century acceleration in global sea-level rise. Geophysical Research Letter, 33: L01602, doi: 10.1029/2005GL024826.

Church, J. A., White, N. J., Coleman, R., Lambeck, K. and Mitrovica, J. X., 2004. Estimates of the regional distribution of sea-level rise over the 1950-2000 period. Journal of Climate, 17, pp. 2609-2625. 


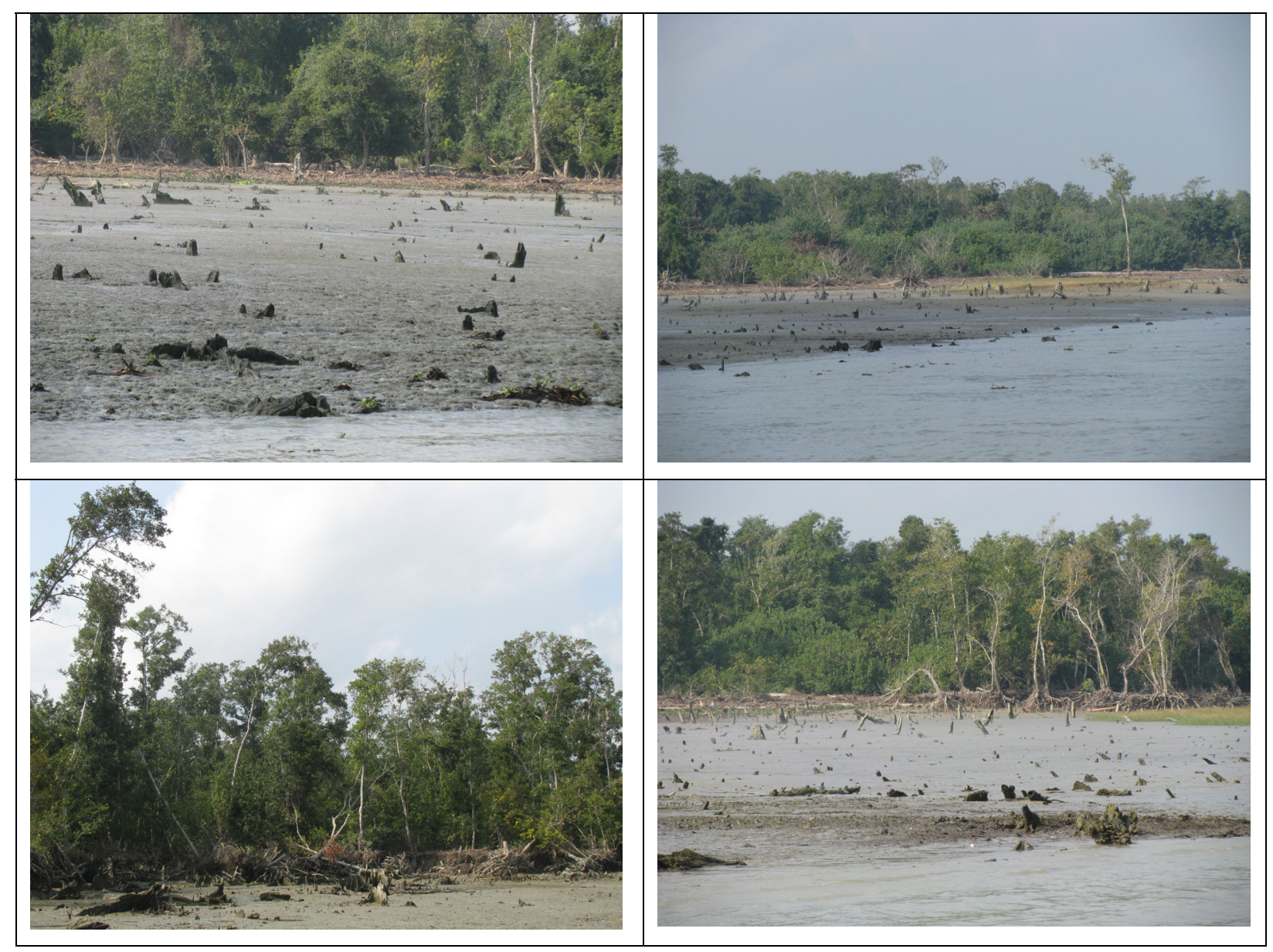

Figure 4. Photographs represent the patterns of coastal erosion in the Sundarbans mangrove forests

Giri, C., Pengra B., Zhu, Z., Singh, A. and Tieszen, L. L., 2007. Monitoring mangrove forest dynamics of the Sundarbans in Bangladesh and India using multi-temporal satellite data from 1973 to 2000. Estuarine Coastal and Shelf Science, 73, pp. 91100.

Holgate, S. J. and Woodworth, P. L., 2004. Evidence for enhanced coastal sea-level rise during the 1990s. Geophysical Research Letter, 31, L07305, doi:10.1029/2004GL019626.

IPCC 2007. Summary for Policymakers. In: Solomon, S., Qin, D., Manning, M., Chen, Z., Marquis, M., Averyt, K. B., Tignor, M. and Miller, H. L., (eds.). Climate Change 2007: The Physical Science Basis. Contribution of Working Group I to the Fourth Assessment Report of the Intergovernmental Panel on Climate Change,Cambridge University Press, Cambridge, United Kingdom and New York, NY, USA.

Reay, D. S. and Grace, J., 2007. Carbon dioxide: Importance, sources and sinks. In: Greenhouse gas sinks. Reay, D., Hewitt, C. N., Smith, K. and Grace, J., (eds.), CABI, UK

Rosenzweig, C., Casassa, G., Karoly, D. J., Imeson, A., Liu, C., Menzel, A. et al. 2007. Assessment of observed changes and responses in natural and managed systems. In: Parry, M. L. et al. (eds.). Climate Change 2007: Impacts, Adaptation and
Vulnerability, Fourth Assessment Report of IPCC, Cambridge University Press, Cambridge, UK, pp. 79-131.

Tans, P., 2010. Trends in atmospheric carbon dioxide, available on-line at NOAA/ESRL (www.esrl.noaa.gov/gmd/ccgg/trends/) (24 Aug. 2010)

UNEP, 2004. The Sundarbans: Mangroves, tigers and shrimp farms, In: Analyzing Environmental Trends Using Satellite Data: Selected Cases. UNEP/DEWA/RS.04-5, Environment Change Analysis Series, UNEP, Nairobi, pp. 31-36. 